NBER WORKING PAPER SERIES

\title{
IS-LM AND MONETARISM
}

\author{
Michael D. Bordo \\ Anna J. Schwartz \\ Working Paper 9713 \\ http://www.nber.org/papers/w9713
NATIONAL BUREAU OF ECONOMIC RESEARCH 1050 Massachusetts Avenue
Cambridge, MA 02138
May 2003

This paper was presented at the 2003 HOPE Conference on "The IS/LM Model: Its Rise, Fall, and Strange Persistence" at Duke University, April 25-27. The views expressed herein are those of the authors and not necessarily those of the National Bureau of Economic Research.

CO2003 by Michael D. Bordo and Anna J. Schwartz. All rights reserved. Short sections of text not to exceed two paragraphs, may be quoted without explicit permission provided that full credit including $\odot$ notice, is given to the source. 
IS-LM and Monetarism

Michael D. Bordo and Anna J. Schwartz

NBER Working Paper No. 9713

May 2003

JEL No. B22, B31, B41, E12, N12

\section{$\underline{\text { ABSTRACT }}$}

This paper discusses monetarist objections to the IS-LM model. We explore the views of two principal spokesmen for monetarism: Milton Friedman and the team of Karl Brunner and Allan Meltzer. Friedman did not explicitly state the reasons he generally chose not to use the IS-LM model in rejecting Keynesian views on the demand function for money, the role of autonomous expenditures in cyclical fluctuations, the potency of fiscal policy as against monetary policy, etc. He presented statistical findings, historical evidence, and econometric results to support his alternative analysis of macroeconomics, but his critics were unconvinced. In 1970, in an effort to use his critics' common language, he set up a model with explicit terms for IS-LM to encompass both the quantity theory and the income-expenditure theory. Friedman attributed the failure of this effort to the fact that he was a Marshallian, his opponents Walrasians.

Brunner and Meltzer's objections to IS-LM were explicit. They found it too spare, so they elaborated it by adding a credit market, disaggregating the asset market by specifying three assets: base money, government debt, and real capital. They set up a model with financial institutions and utilized it to study the effects of a variety of policies.

In brief, summarizing the views of both Friedman and Brunner and Meltzer, monetarists dislike the IS-LM framework because it limits monetary influence too narrowly, essentially to the interest elasticity of money demand, and defines investment in an excessively narrow fashion, and even that is not explicit.

Michael D. Bordo

Dept. of Economics

Rutgers University

New Jersey Hall

New Brunswick, NJ 08901-1284

and NBER

bordo@economics.rutgers.edu
Anna J. Schwartz

National Bureau of Economic Research

365 Fifth Avene, $5^{\text {th }}$ Floor

New York, NY 10016-4309

aschwartz@gc.cuny.edu 


\section{IS-LM and MONETARISM}

\section{Introduction}

Monetarism is the name that the late Professor Karl Brunner of the University of Rochester gave in 1968 to propositions about the relation between money and other economic variables - such as income, prices, interest rates - propositions that Keynesian economists of that date and earlier denied. Specifically, monetarists regarded the relation between money balances and nominal income as a strong one and Keynesians regarded it as a weak one. Even the view of inflation as a monetary phenomenon, a core monetarist proposition, to many Keynesians before 1970 was unacceptable. ${ }^{1}$ There is no canon, however, that one can consult to establish the orthodox monetarist position. Proponents of monetarism all accept the quantity theory of money as the explanation of inflation and deflation, although they differ on the importance of selected building blocks of the approach. ${ }^{2}$

Although there is no canon of monetarist views, two principal spokesmen for monetarism can be named. They are Milton Friedman on the one hand and, on the other, the team of Karl Brunner and Allan Meltzer, even if their individual versions are not invariably identical. It is their views that we shall explore in later sections of our paper.

Our task is to study elements of the IS-LM model that the spokesmen for monetarism we have singled out rejected. First developed by John Hicks in 1937, the IS-LM model was an attempt to portray the central ideas of Keynes's General Theory. The model was widely adopted in teaching macroeconomics in the decades that followed. Section 2 describes equilibrium in the

\footnotetext{
${ }^{1}$ See Bronfenbrenner and Holzman (1963) for a non-monetarist survey of inflation theory. Johnson (1971) refers to inflation as "the issue Keynesian theory was least well designed to deal with" (p.7).

2 According to Mayer (1978) there are 12 characteristic monetarist propositions, but he suggests that readers may choose to add or delete items from his list. Purvis (1980) lists eight as most basic, but adds "one can believe some
} 
investment and savings market and in the money market as defined by the IS-LM model, and the evolution of the model since the 1960s.

Section 3 presents Friedman's alternative analysis of macroeconomics in the years between 1956 and 1970. He contrasted it with the Keynesian version, describing the basic differences between the two. If IS-LM is the distillation of The General Theory, it suited Friedman better to confront the source rather than the distillation. His objections to the IS-LM model, however, are implicit since he never directly stated what they were. The General Theory simply did not express his own conception of how the macroeconomy functioned. His description of the features of the economy that he regarded as crucial was expressed in a language that was not consistent with the language most economists used to explain an explicit model like IS-LM. So there was no engagement with the IS-LM model when Friedman presented his views. This observation must be qualified in one respect. In an essay responding to the charge that the omission of an interest rate variable in his study of velocity (1959) implied that money was divorced from the real sector, Friedman (1966) introduced Hicks's IS-LM analysis. It is not necessary for our purpose to report his use of different versions of the analysis to defend the view that, inclusion of the interest rate in the demand for money equation is neither a necessary nor a sufficient condition for the divorce of money from the real sector.

While Friedman did not explicitly state the reasons that he generally chose not to use the IS-LM model to discuss his rejection of Keynesianism, we can summarize one or another aspect of the views that he challenged in his publications. It is interesting, nevertheless, that he lectured on IS-LM in the graduate course in macroeconomics that he taught for the first time in 1967 , evidently to acquaint his students with the language that he customarily spurned in his analytic

without believing others" (p. 98). Laidler (1981) discusses four key characteristics of monetarism. Hoover (1988, p.10) identifies two criteria as defining monetarists. 
work. In 1970, however (published 1974), in an effort to facilitate communication with his critics, Friedman phrased his arguments in terms of IS-LM. The effort proved unsuccessful. Friedman later (2001) concluded, "It was really a waste, I think, trying to reconcile the Keynesian thinking with the monetarist thinking." Friedman did not say outright why expressing his views with the IS-LM formulation did not achieve the reconciliation that he sought. His shorthand explanation was that he was a Marshallian, and his opponents were Walrasians. It is possible, however, to note some concrete differences that we shall detail.

In section 4 we turn to the explicit objections to the IS-LM model that Brunner and Meltzer posed at different stages in their treatment of the subject. We discuss an early version and a later version of their dissatisfaction with the model. They sought to amend the model, unlike Friedman, who in the main disregarded it.

In section 5 we conclude by discussing the evolution of the IS-LM model in the decades since it came into common use in the heyday of the monetarist-Keynesian debate. It has survived and prospered as a pedagogical device for undergraduate economics at the intermediate level. The monetarist debate is moribund but the main tenets of monetarism have been incorporated in the New Keynesian Synthesis model that has succeeded IS-LM as the apparatus used for technical and policy discussions.

\section{IS-LM from Hicks to Friedman}

Hicks (1937) synthesized in a simple general equilibrium model the central argument of the General Theory and compared it to the position of the classical economists. The model had two markets: the market for goods and the money market. ${ }^{3}$ In the goods market, investment is

\footnotetext{
${ }^{3}$ Hicks (1937) assumes rigid money wages. Also income is derived from a two sector model consisting of consumption and investment goods which in turn are functions of employment in the two sectors.
} 
assumed to be a negative function of the interest rate -- Keynes's marginal efficiency of capital schedule -- savings a positive function of income -- derived from Keynes's marginal propensity to consume -- and of the interest rate. ${ }^{4}$ The equality of investment and savings clears the market. The solution of these three equations produces the IS curve, a negative relationship in interest rates, nominal income space. A rise in the interest rate reduces investment and via the multiplier also income.

In the money market, Hicks distinguishes the Keynesian demand for money or liquidity preference function -- a negative function of the interest rate -- from the classical Cambridge cash balance equation where money is solely a positive function of income. In a more general Keynesian model, money demand depends on both income -- the transaction demand -- and the interest rate -- the speculative demand. Money supply is assumed to be fixed by the central bank. From the equality of money demand and supply, the LM curve is derived as a positive function in interest rates, nominal income space. A rise in income increases money demand, which requires a rise in the interest rate to restore equilibrium.

Hicks then uses his apparatus to delineate the salient differences between the Keynesian and classical positions. In his analysis, he maintains the assumption of wage rigidity in both models so that the key difference between the two models is the money demand function used, and hence the shape of the LM curve. In the pure Keynesian case LM is horizontal -- interest elastic (absolute liquidity preference). In the pure classical case it is vertical -- interest inelastic. Whether monetary policy can stimulate the economy then depends on whether IS intersects LM in the Keynesian (flat) zone of LM to the left of the diagram or the classical (steep) zone to the right.

\footnotetext{
${ }^{4}$ In a more general model, Hicks also includes income in the investment function.
} 
Many components of the Hicksian apparatus were developed by his contemporaries (Meade, Harrod, Champernowne, Reddaway) but Hicks is remembered because he embedded it in a simple compelling diagram (Darity and Young (1995), De Vroey (2000)). Although we always think of Hicks when discussing IS-LM, his model is not the direct antecedent of the popular textbook model commonly used since the 1950s. Hick's assumption of wage rigidity in both Keynesian and classical models made it difficult to interpret the classical case (De Vroey 2000). Indeed, the model adopted by the textbooks, that Friedman used in his debate with his critics in the early 1970s, was developed by Modigliani (1944). That model of the labor market explicitly distinguished between the Keynesian and classical cases. In the classical case, labor demand and supply are both functions of the real wage and prices and wages are perfectly flexible, so that full employment and the full employment level of output are determined. In the Keynesian model the assumption of a rigid money wage leads to a perfectly elastic supply curve for labor and movements in labor demand lead to movements in employment and output.

For Modigliani the key difference between Keynes and the classics was wage rigidity, which leads to a less than full employment equilibrium. He viewed absolute liquidity preference as a curiosity and not the true hallmark of the Keynesian model.

The Hicks Modigliani model was then popularized by Hansen (1953). The simplest textbook version of the 1950s assumed price rigidity and operated in interest rate, real income space. Other popular textbooks of the era (e.g., Dernberg and MacDougal (1960), Ackley (1961), followed the Hansen lead. A more sophisticated extension of the Modigliani model that provided the framework used by Friedman in his 332 course at the University of Chicago in the late 1960s and later appeared in his debate with the critics in the early 1970s, is developed in Bailey (1962). In that framework, the classical model with fully flexible wages and prices was 
elucidated in an IS-LM diagram where the IS and LM curves intersect the full employment level of output shown as a vertical line and derived from Modigliani's labor market equations. Various Keynesian cases (wage rigidity, absolute liquidity preference, interest inelastic investment and savings) then follow as special cases of the mere general model.

\section{Friedman. Bypasses IS-LM Before 1970}

Instead of directing his criticisms to the shorthand version of the General Theory (1936), represented by IS-LM, Friedman directly attacked the thinking on which the book was based. For Friedman, the gist of Keynes was that money did not matter. Keynes believed that any change in the supply of money in the main would be offset by a change in velocity. Thus he regarded the quantity theory equation in its Cambridge cash-balance version, $\mathrm{M}=\mathrm{kPY}$, to be valid as an identity but useless for policy or for predicting short-run fluctuations in income, which Keynes treated as if there were no difference between nominal and real income.

Each of the Keynesian ideas and Friedman's alternative are presented in the works he published at various dates before 1970, the year he first defined his approach in terms of the ISLM model. Friedman in turn became the target of criticism by defenders of Keynes. We also review the disputes.

\section{A. The Liquidity Trap versus A Stable Demand Function for Money ("The Quantity}

Theory of Money: A Restatement" (1956)). The essay presented the quantity theory as a theory of the demand for money. To households money is one kind of asset, one way of holding wealth. To firms, money is a capital good that combined with other sources of productive services yields the products that firms sell. Friedman interprets the theory of the demand for money as a special topic in the theory of capital. 
The demand for money by households, like their demand for other consumption services, is dependent on total human and nonhuman wealth (the budget restraint), the expected price of and return on money and alternative forms of wealth, as well as intertemporal rates of substitution, tastes and preferences of household wealth holders. Friedman distinguishes between real and nominal magnitudes and casts the demand for money by households as a demand for real balances -- a function of real variables independent of nominal money values.

A firm's demand to hold more or less money, like their demand for other productive services, depends on the cost of the productive services money yields, the cost of substitute productive services and the value of the product the productive service yields. Like the household the firm's demand for money is a demand for real balances, responsive to rates of return on bonds, equities, and on other assets as well as the rate of change of the price level.

From Friedman's viewpoint, the Keynesian distinction between "active balances and "idle balances" and "transaction balances" and "speculative balances" is irrelevant. Each unit of money renders a variety of services that the household or firm equates at the margin.

According to Friedman, three issues account for the difference of opinion between someone who is and someone who is not a quantity theorist. The first issue is that a quantity theorist accepts the empirical hypothesis that the demand for money is highly stable, more so than the consumption function that Keynes offered as an alternative. The quantity theorist assigns a key role to the demand for money in determining such variables as the level of nominal income or of prices. Rejection of the quantity theory has been based on the assertion that the demand for money is unstable and that it is not possible to specify a limited number of variables on which it depends. 
A second issue is that the quantity theorist regards the supply of money as affected by factors other than those affecting the demand for money.

A third issue is that Keynes asserts that under conditions of underemployment, when interest rates are positive but low, a liquidity trap exists such that the demand for money becomes infinitely elastic. Changes in the real supply of money then have no effect at all.

Of all the commentators on Friedman's restatement of the quantity theory Don Patinkin $(1969,1970)$ offered the most critical appraisal. He did so not on grounds that its substance was flawed, but for three incidental shortcomings. One, it was an improper representation of the traditional quantity theory. Two, it was a misinterpretation of doctrinal history, of the shift from the transaction approach to the income version, to the cash-balance version of the quantity theory and the Keynesian income-expenditure approach. Finally, in Patinkin's view, Friedman should have acknowledged that his analysis was far closer in its conceptual framework to Keynes's liquidity preference theory than to that of the quantity theory. Friedman denies each of Patinkin's strictures, particularly the one that terms Friedman's formulation of the demand for money a riff on Keynes's liquidity preference theory.

\section{B. Testing the Keynesian Multiplier versus the Velocity of Money ("The Relative} Stability of Monetary Velocity and the Investment Multiplier in the United States, 1897-1958” (with David J. Meiselman) (1963)). This study predicts consumption expenditures in the US for the 6 decades since 1897, using annual data, and for a shorter period, using quarterly data. Two equations represent the competing hypotheses, one with the stock of money as the independent variable, the other with Keynes's definition of investment, i.e., autonomous expenditures. Three comparisons were reported, one in real terms, one in nominal terms (a price variable was added to each of the equations), and a multiple regression with both autonomous expenditures and 
stock of money as independent variables in the same equation. The relative accuracy of forecasts of consumption predicted by the two competing hypotheses was the issue. The correlation coefficient for the full period for the money equation was 0.98 , and for the autonomous expenditure equation, 0.76 . Results for subperiods were similar. The multiple regressions with both autonomous expenditures and money as independent variables in the same equation that showed a partial correlation of consumption with autonomous expenditures were interpreted as reflecting a correlation between money and autonomous expenditures. Friedman and Meiselman conclude that the simple version of the income-expenditure theory is "almost completely useless as a description of stable empirical relationships" (p. 187).

Early on three articles appeared attacking the work: Ando and Modigliani (1965); DePrano and Mayer (1965); Hester (1964). Ando and Modigliani dismiss the tests as meaningless for either the prediction or control of income. Their reason is that the independent variables are not shown to be exogenous to the system, and that the competing means of stabilization are parts of the single Keynesian general equilibrium system. They maintain that tests they perform substituting for actual money data a measure of money that is the maximum that can be created given the supply of reserves excluding borrowed reserves confirm the Keynesian position that the interaction of monetary and real forces determines income, and that after eliminating trend the contribution of money supply to income fluctuation was at most slightly over one-third. DePrano and Mayer find specification errors in the models, and conclude that both autonomous expenditures and money are of roughly equal importance. Hester labels Friedman and Meiselman's finding false because their definition of income excludes taxfinanced government expenditure; their use of net rather than gross private domestic expenditure 
biases the correlation coefficient for autonomous expenditure toward zero; and in the period from 1930 to 1958, the autonomous expenditure theory outperformed the quantity theory.

Friedman and Meiselman in answer to their critics note that focusing on overarching theories and theoretical models is not the way to discriminate between empirically verifiable and unverifiable hypotheses. They decry the absence of an unambiguous criterion of the most useful empirical counterpart for autonomous expenditure as there is about the counterpart for money. Because the critics omit some components of income for the income-expenditure calculations their results are incorrect, according to Friedman and Meiselman.

\section{Keynesian Investment versus Money Stock in Business Cycle Fluctuations ("Money} and Business Cycles" (with Anna J. Schwartz)(1963)). This conference paper is divided into two parts. The first part reports factual evidence on the behavior of money during NBER business cycles from 1867 to 1961 . We do not summarize that evidence at this juncture. It is reported below in the comments of the critics on individual findings about the behavior of money.

The first part ends with a statement concerning the Keynesian position, which regards the rate of cyclical expansion or contraction as fairly rigidly determined by the rise or fall in investment or autonomous expenditure, with this link far more crucial than any link with the contemporary behavior of the money stock. The statement is followed by an assessment of the relative roles of money and investment by correlating (1) the variability of annual changes in money with the variability in annual changes in consumption, and (2) the variability of annual changes in investment with the variability of annual changes in consumption. The synchronous correlation coefficients are consistently higher, both for the period as a whole and for the period since 1899 (when income figures require less interpolation) for money-consumption variability than they are for investment-consumption variability. These results are the same as for the 
Friedman-Meiselman study, though, derived by a different methodology, from first differences of logarithms and moving standard deviations of the first differences. For a given stock of money, these results suggest that there is no systematic relationship at all between autonomous expenditures and consumption.

The second part of the conference paper presents interpretations of the factual evidence. The factual evidence shows that the stock of money displays a consistent cyclical behavior, which is closely related to the cyclical behavior of the economy, but is not decisive about the direction of influence. One relevant factor cited in the paper is that, despite substantial changes in arrangements determining the quantity of money over the period, the changes have not altered the relation between business changes and monetary changes. More convincing evidence that money plays an important independent part cited next is the historical record of major economic fluctuations, including deep depressions, substantial inflations, and a few long-continued movements in one direction. These events justify two generalizations: (1) Disturbances in the rate of growth of the money stock in every case are accompanied by changes in money income and prices in the same direction and of appreciable magnitude, and there are no comparable disturbances in the rate of growth of the money stock unaccompanied by changes in money income and prices. (2) The changes in the stock of money can generally be attributed to specific historical circumstances that are not attributable to contemporary changes in money income and prices. The consistent relation between money and income must reflect an influence running from money to business. The demonstration that the major changes in the stock of money have been attributable to a variety of sources connected directly neither with contemporary nor earlier business developments contradicts an explanation of the one-to-one relation between monetary change and major economic change as a relation running from economic change to money. 
Hence appreciable changes in the rate of growth of the money stock are a necessary and sufficient condition for appreciable changes in the rate of growth of money income. This is true, it is argued, both for long secular changes and for changes over business cycles. Secular changes in money income produced by a changed secular rate of growth of the money stock are reflected mainly in different price behavior rather than different rates of growth of output. Shorter period changes in the rate of growth of the money stock can exert a considerable influence on the rate of growth of output as well. This is the case for monetary fluctuations as the source of major movements in economic fluctuations.

The case for a monetary explanation of minor economic fluctuations is not nearly so strong, the paper concedes. The view that monetary change is important does not preclude the existence of other factors that affect the course of business or that account for the rhythmical character of business fluctuations. What is needed to explain minor movements is a specification of the distribution of the random disturbances impinging on the economy and a specification of the systematic disturbances that can be introduced into it as well as the reaction mechanism of the economy. That explanation is not yet at hand.

The paper includes a theory that accounts for the observed tendency of cyclical fluctuations in income to be wider in amplitude than cyclical fluctuations in money. The theory yielded an independent statistical estimate of the ratio of the percentage change in income to the associated percentage change in the stock of money of 1.84. The directly observed ratio was 2.0 .

The paper concludes with a sketch of the transmission mechanism that could explain how monetary changes produce cyclical fluctuations in income. The mechanism emphasizes adjustment of stocks to flows with money playing a key role as a component of the stock of assets. Balance sheet adjustments are important. Money's effects are transmitted through a 
wider channel than the interest rate on financial assets. It includes prices of sources of services of durable and semi-durable consumer and producers goods as well as the prices of the goods that yield a flow of services

Two discussants of the paper were critical. Hyman Minsky argued that the paper failed to make a convincing case that monetary changes fully explain observed business cycles. $\mathrm{He}$ would agree only with a proposition that there should be fuller integration of monetary phenomena into the basically income-expenditure models. For Arthur Okun the estimate of the money multiplier effect on national income of an increase in money was unbelievable, given the much smaller estimated combined multiplier-accelerator effects on national income of fiscal action comparable in size to the monetary increase. He faulted the paper for the larger estimate of the leverage of money as the consequence of associating the demand for money with permanent income that varies from year to year by an estimated one-third as much as aggregate measured income; then assuming that demand for and supply of money are equilibrated by changes in measured income, a change in the money supply must induce magnified income changes. Okun also challenged the view of money as a luxury good with a long-run income elasticity of the demand estimated as 1.8. (In a later study of trends by Friedman and Schwartz (1982), this estimate of the long-run income elasticity of the demand for real money balances was lowered to allow for growth of financial sophistication in the US before 1903.) With respect to the transmission mechanism the paper described, Okun expressed surprise that it was similar to the one he visualized.

The third discussant, Clark Warburton, gave generally favorable comments. Complementing and amplifying the cyclical evidence was historical evidence that Friedman and Schwartz provided in A Monetary History of the United States, 1867-1960. 
Written within the framework of the quantity theory although without an explicit model, the history documented a close relationship between money and nominal income and the price level. It also documented the short-run relationship between changes in money and changes in real income, revealed most dramatically in episodes of deep recessions, especially the Great Depression of 1929-33. In addition, institutional evidence identified independent sources of monetary changes such as wartime fiat money issues and gold discoveries. See Lucas 1994; Miron 1994; Summers 1991.

\section{Keynesian Fiscal vs Friedman Monetary Policy ("Monetary vs Fiscal Policy: A}

Dialogue, Milton Friedman/ Walter W. Heller" (1969)). Heller argued that the issue was not which policy made a more significant contribution to economic stabilization, since Keynesian economics assigned an important role to both. The issues were two-fold, whether only money matters, disregarding interest rates and credit availability, and whether the Fed should have discretion or be bound by a rule. On fiscal policy, the issues again were two-fold, how much budget cuts or tax changes contributed to stabilization, and whether there should be rigid rules or discretion to modify procedures for cutting or boosting taxes. Money was resurrected by the Accord of 1951, but was threatened by Friedman's money-supply peg. Heller addressed eight questions for Friedman to answer before money was given dominance over fiscal policy. He pleaded for joint efforts to develop a more complete model to ascertain why the economy worked far better than it did before active fiscal monetary policy came into play. Heller then argued for the potency and effectiveness of fiscal policy and for continued and expanded use of discretionary policy.

Friedman's response to Heller was that money matters a great deal for nominal income and prices in the long run and has an important effect on fluctuations in nominal and real income 
in the short run. Money does not matter, however, over the long run for real magnitudes. The real wealth of a society depends on its institutional structure, the abilities, initiatives, driving force of its people, on investment potentialities, on technology. How many dollars the output will be valued at is the issue for which money matters. Both fiscal and monetary policy have been oversold because fine tuning of both has been oversold. Friedman contended that we have the ability to avoid extreme fluctuations and to correct past mistakes, but we do not know enough to fine tune to eliminate minor fluctuations. We know there is a close relation on average between monetary changes and nominal income changes, but the relation is not precise enough to predict from changes in money in one quarter what's going to happen one or two quarters later. That is the reason Friedman favored a rule.

With respect to fiscal policy, according to Friedman, the state of the government budget matters for many things, but by itself it has no significant effect on the course of nominal income, on inflation or deflation, or on cyclical fluctuations. The influence of fiscal policy needs to be separated from the influence of monetary policy since changes in both occur at the same time. Friedman formulated two questions: What happens if monetary policy is held constant and fiscal policy is changed? What happens if fiscal policy is held constant and monetary policy is changed?

He answered the questions by noting that fiscal policy can change without a change in monetary policy. For example, a tax cut can be financed by government borrowing from the market; in which case interest rates but not money supply will be affected. Alternatively, a tax cut can be financed by printing money to cover the deficit. The essence of the claim for the potency of fiscal policy, Friedman argued, is that it doesn't matter how a tax cut is financed. 
Fiscal policy could be potent if indirect effects were strong, but no statistical empirical evidence supported Heller's assertion that the 1964 tax cut by itself was expansionary. That assertion ignores what monetary policy was doing at the same time. The same observation applies to the assertion that the 1966 surtax was contractionary.

According to Friedman, statistical evidence is available on the relative potency of fiscal and monetary policy. He cited his study of monetary and fiscal magnitudes during three war periods. It demonstrates that it was monetary, not fiscal, magnitudes that explain wartime price behavior. In Friedman and Meiselman's study, monetary effects on income outperformed autonomous expenditure, the Keynesian driving variable, in their effects on income. The St. Louis study by Andersen and Jordan (1968) confirmed that the response of economic activity from 1952 to 1968 was larger, more predictable, and faster for money than for fiscal variables.

Friedman challenged proponents of the importance of fiscal effects for inflation and the price level to offer evidence to support their assertions.

Heller replied that Keynesians use complete models of the economy rather than oneequation systems to formulate more interesting questions than the simple one of whether fiscal or monetary policy is paramount. His view was that one cannot test and measure the effects of policy on the economy without a correctly specified model. The models show that fiscal policy matters a great deal.

In Friedman's rebuttal, he denied the Keynesian position that tax increases or expenditure decreases were equivalent and that they are an effective stabilization device. Since he regarded the US federal government budget as excessive, he favored expenditure decreases, rather than tax increases. Friedmam concluded by answering some of the eight questions about money that Heller posed in his opening statement. 
In the foregoing studies the debate between Keynesians and monetarists was joined. Although the discussion touched on different relationships embodied in the IS-LM model and the roles of monetary and fiscal policy, they were not spelled out in terms of a general equilibrium model. One reason that Friedman preferred single equations rather than testing general equilibrium models was his long-standing position that he was a Marshallian. That meant focusing on particular problems of economic analysis, using theory as "an engine for the discovery of concrete truth." In this approach, hypotheses need to be tested by the accuracy of their predictions. Friedman explicitly rejected the alternative Walrasian paradigm of "general equilibrium" that emphasizes the realism of its assumptions and is characterized by "abstractness, generality, and mathematical elegance" (Hirsch and DeMarchi 1990; Hammond 1996).

Friedman had tried to establish the validity of his work in monetary economics by presenting statistical findings, historical evidence, and econometric results, but his efforts had not succeeded. His opponents did not confront him with conflicting empirical evidence. Instead, his critics, who were not exclusively Keynesians, charged that monetarists relied on a black box instead of providing a credible explanation of how monetary policy was transmitted to the real economy. They said that there was no underlying theoretical model of the economic structure corresponding to Friedman's empirical findings. A persistent complaint was that Friedman had not demonstrated the exogeneity of money. ${ }^{5}$ In general, the critics found that identification problems marred Friedman's formulations. Moreover, statistical correlation was all that accounted for the importance he claimed for money.

\footnotetext{
${ }^{5}$ Friedman's argument that a variable could be exogenous in some contexts and endogenous in others, depending on the issue, was not addressed by his opponents.
} 
A critique by Tobin (1970) was particularly effective in buttressing opposition to Friedman's treatment of money. To dispute the use of timing patterns as a basis for the claim that monetary actions preceded income changes, Tobin constructed models that produced simulated patterns of money and income. The Keynesian model has money leading income although money does not determine income. The monetary model has money lagging income in time, yet money determines income. ${ }^{6}$

Friedman was frustrated by the fact that he and his critics were talking past one another. They were Walrasians, he was a Marshallian. That accounted for the communication failure. The solution, Friedman thought, was to encompass both the quantity theory and the incomeexpenditure theory in one model that included explicit terms for IS and LM. This was the monetary framework that he presented in 1970.

Robert Gordon invited four critics to assess Friedman's attempt to communicate across doctrinal differences. The critics did not appreciate that Friedman was trying to provide a framework in order to discriminate between alternative hypotheses. In acknowledging that $\mathrm{Y}=$ $\mathrm{kA}$ and $\mathrm{Y}=\mathrm{vM}$, he offered the Keynesian model as a particular case and the quantity theory model as an alternative case of a more general model that he specified, but he was unsuccessful in closing the model. In retrospect Friedman concluded that his attempt to reconcile the quantity theory with the income-expenditure theory was a waste of time. ${ }^{7}$ Expressing monetarist analysis in IS-LM terms did not clarify the issues dividing Marshallians and Walrasians.

Jerome Stein organized a conference at Brown University in 1974 to try once more to sort out the differences between Friedman and his critics. Purvis (1980), commenting on the

\footnotetext{
${ }^{6}$ Tobin's critique essentially condemned Friedman's work because it lacked an explicit model that specified cause and effect relations before undertaking measurement and estimation. See Hammond 1996, p. 138.

${ }^{7}$ Purvis (1980) notes that despite dissatisfaction with IS-LM and some of the shortcomings of Keynesian conventional wisdom, the alternative Friedman offered of "virtual constant full employment" had little appeal.
} 
subjects the conference considered, thought the major issue should have been whether stabilization policies were desirable. Disagreement centers on alternative theories of the causes of unemployment. IS-LM treats deficient aggregate demand as the primary cause. Recent emphasis, however, is on aggregate supply. Differences in theories of aggregate supply and the determinants of output are the issue the Brown conference neglected.

The Brown attempt at reconciling monetarist and Keynesian views was futile. For the critics monetarism lacked a broad theoretical foundation. For Friedman different theories were appropriate for different problems. Carving up a broad issue into smaller parts that could be studied empirically produced more precise results than a big structural model with hundreds of equations. The division between the opposing sides seemed more acute when lined up as Marshallians vs. Walrasians than as monetarists vs. Keynesians.

\section{Brunner and Meltzer Elaborate the IS-LM Model}

The definitive statement by Karl Brunner and Allan Meltzer concerning the problems they perceived with IS-LM is contained in the second of the four Raffaele Mattioli Foundation lectures they gave in Milan at Bocconi University in August 1988 (published in 1993). (Earlier versions of the model in the lecture appeared in Brunner $(1971,1974)$, Brunner and Meltzer $(1972,1976)$.

The co-authors describe IS-LM with the addition of the Phillips curve as a model of stock-flow interactions consisting of two equations, the equilibrium conditions for the asset and output or income markets.

IS: $y=f(i, M / p)$

LM: $M / p=g(i, y)$ 
$\mathrm{M}$ is predetermined or given, $\mathrm{p}$ is either given or obtained from the Phillips curve. Other variables may be added.

The co-authors review early uses of IS-LM by Keynesian economists. Some treated money as a substitute for bonds or financial assets only. Until the 1950s the monetary mechanism was viewed as sensitive to the system's interest elasticities, which contrasted with more reliable, direct effects of fiscal policy. Interest rates were interpreted as borrowing costs borrowers paid to finance investment projects, but studies reported that borrowing costs were trivial. The upshot was that the interest elasticity of aggregate demand was negligible, and the IS line relatively steep. Hence stabilization policy had to rely on fiscal policy, and the role of monetary policy was to keep borrowing costs low.

In the late 1950s, the concerns of IS-LM users shifted. Monetary policy effects were concentrated on the housing market where borrowing costs were important, but politics limited the use of monetary policy to keeping interest rates low.

Other users of IS-LM recognized that money is a substitute for the whole spectrum of both financial and real assets. One interpretation was that bonds and real capital have identical rates of return, so financial markets have to keep the two returns identical. This assumes active financial markets. However, relations between money, income, and prices exist with primitive or non-existent financial markets. Further, the co-authors demur, portfolio adjustments are delayed by transactions and information costs. Also risk distributions for all real and financial assets are not always and everywhere identical. Accordingly, bonds and capital are not always perfect substitutes.

The co-authors believe that neither the interpretation of money as a substitute for bonds only or as a substitute for a full range of assets includes analysis of main aspects of financial 
markets and of portfolio allocations affecting the relation of money to income and prices. IS-LM has no markets for credit or bank loan rationing. Shocks affecting the credit markets are treated as shocks to the demand for money. The two sets of shocks have different consequences. Income effects on loan demand and on the credit market in the IS-LM model must also be treated as a shift in the demand for money. IS-LM analysis cannot accommodate intermediation and disintermediation and their effect on transmission of monetary and real impulses. Deregulation is outside the scope of IS-LM.

For these reasons Brunner and Meltzer regard the analysis of monetary policy in the ISLM framework deficient. A single interest rate misrepresents the problem central banks confront and may mislead them to believe that they control interest rates. It is not possible to understand the effects of permanent and transitory shocks as well as real and nominal shocks on the relation between rates for different maturities and on real and financial assets within the IS-LM framework.

Brunner and Meltzer proceed to elaborate the framework. They add a credit market, and introduce three assets, base money, government debt, and real capital. They are less than perfect substitutes in portfolios. Money differs from the other two assets because of its services in a world of uncertainty. The public may hold the three assets or exchange securities for loans from financial institutions. These institutions determine separate rates for each liability they offer in response to market conditions. The co-authors specify the equilibrium conditions of the credit market and money market, respectively. They set up a model with the government budget constraint, an aggregate supply function, and an aggregate demand function which involves solving for equilibrium in the goods and asset markets. Equilibrium in the money and credit markets involve the banking system money supply and credit demand multipliers. 
The core of the Brunner and Meltzer model is its emphasis on disaggregated asset markets. Dornbusch (1976) questions the value added of disaggregated asset markets and the manner in which the model translates monetary and fiscal actions into changes in prices and output. The transmission channels in the aggregate demand function involve interest rate and wealth effects. Dornbusch discounts the authors' claim that their model provides a more pervasive adjustment mechanism than in Keynesian models. Finally, he questions the extent to which the Brunner and Meltzer model qualifies as monetarist.

Purvis (1980) finds the multiasset feature in Brunner and Meltzer's work to be an important departure from the IS-LM straight jacket but a "total red herring" as marking its distinction from eclectic Keynesian analysis.

\section{IS-LM and Monetarists Today}

IS-LM has survived all of its criticisms over the years and is alive and well in the intermediate macro textbooks. The reason it is still used is the same reason that it won over its competitors - over sixty years ago - it is simple, elegant and easy to manipulate for expository purposes. However, as Colander (2003) points out, its use is no longer as the common language for debates among monetary theorists over the issues of high theory as it was 30 years ago, but rather as a classroom device to point out to undergraduates the economic impact of alternative macroeconomic policies. It is also still the workhorse of open economy macroeconomics and the IMF in its evaluation of member countries' economic balance (Darity and Young 2003, Boughton 2002). Finally it has now been endowed with the legitimacy of microfoundations based on optimizing behavior by households and firms (McCallum and Nelson1999). 
Yet while IS-LM has survived, the monetarist Keynesian debate that so consumed the profession 30 years ago is moribund. Today the synthesis that unites theorists and policymakers is the New Keynesian model which like IS-LM, is a general equilibrium model with nominal rigidities but also incorporating optimizing micro behavior, rational expectations, and policy rules. Although this model is used to evaluate and conduct monetary policy, it does not actually have money in it nor an explicit LM function.

The model has three equations: an IS equation where the output gap (actual less potential GDP) depends on the real interest rate (the nominal rate minus rationally expected inflation); a Phillips curve, which relates the inflation rate to the output gap and to both past inflation and rationally expected future inflation; a policy rule (commonly the Taylor rule), which relates the short-term interest rate (in the U. S. the Federal Funds rate), the central bank's policy instrument, to the output gap and the difference between inflation and the central bank's inflation target (Meyer 2001).

Although the model does not have an LM curve in it, one can be added on to identify the amount of money (high-powered money) that the central bank will need to supply when it follows the policy rule, given the shocks that hit the economy (McCallum 1999). However this fourth equation is not essential for the model.

Yet although money is now missing from the mainstream macro model, the lessons of monetarism have not been ignored. Incorporated in the model are a number of Friedman's main tenets: that inflation is always and everywhere a monetary phenomenon and can be controlled by monetary policy; that monetary policy in the short-run has important real effects because of the presence of nominal rigidities or lags in the adjustment of expected to actual inflation; i.e., that in the long run the Phillips curve is vertical, as expected inflation adjusts to its actual level; that 
there is a distinction between nominal and real interest rates embodied in the Fisher equation; and that policy rules are important anchors to stable monetary policy.

Moreover Brunner and Meltzer, working in the Walrasian tradition, incorporated a number of these tenets into the general equilibrium models that they developed in the 1960s and 70s. Their work thus served as an important building block to the modern synthesis.

In sum, Friedman's main criticism of Keynes - - that money matters (in the long run for inflation and in the short-run for output - - has survived and prospered and is at the heart of both the synthesis model and the emphasis today on low inflation as the key policy goal of the world's leading central banks. 


\section{$\underline{\text { References }}$}

Ackley, Gardner. 1961. Macroeconomic Theory. New York: Macmillan.

Andersen, Leonall, and Jerry L. Jordan. 1968. "Monetary and Fiscal Actions: A Test of Their Relative Importance in Economic Stabilization." Federal Reserve Bank of St. Louis Review 50:11-23.

Ando, Albert, and Franco Modigliani. 1965. "The Relative Stability of Monetary Velocity and the Investment Multiplier." American Economic Review 55:693-728.

Bailey, Martin. 1962. National Income and the Price Level. New York: McGraw Hill.

Boughton, James. 2002. " On the Origin of the Fleming - Mundell Model.” IMF Working Paper 02/107. Washington D.C. International Monetary Fund.

Bronfenbrenner, Martin, and Franklin D. Holzman. 1963. "Survey of Inflation Theory." American Economic Review 53: 593-661.

Brunner, Karl. 1968. "The Role of Money and Monetary Policy." Federal Reserve Bank of St. Louis Review 50: 8-24.

Brunner, Karl. 1971. "A Survey of Selected Issues in Monetary Theory.” Schweizerische Zeitschrift fur Volkswirtschaft und Statistik 107: 1-147.

Brunner, Karl. 1973. "Credit Market, Interest Rate and Three Types of Inflation.” Kredit und Kapital.

Brunner, Karl, and Allan H. Meltzer. 1972. "Money, Debt, and Economic Activity.” Journal of Political Economy 80: 951-977.

Brunner, Karl, and Allan H. Meltzer. 1976. "An Aggregative Theory for a Closed Economy” in Jerome Stein (ed.) Monetarism. Amsterdam: North-Holland, 69-103. 
Brunner, Karl, and Allan H. Meltzer. 1993. Money and the Economy Issues in Monetary Analysis. New York: Cambridge University Press.

Colander, David. 2003. “The Strong Persistence of the ISLM Model.” Paper prepared for the HOPE conference on “ The ISLM Model: Its Rise, Fall and Strong Persistence.” Duke University. April 25-27, 2003.

Darity Jr., William, and Warren Young. 1995. "IS-LM: An Inquest." History of Political Economy 27: 1-41.

Darity, William, and Warren Young. 2003. “IS-LM-BP: an Inquest.” Paper prepared for the HOPE conference on “ The ISLM Model: Its Rise, Fall and Strong Persistence.” Duke University. April 25-27, 2003.

DePrano, Michael, and Thomas Mayer. 1965. “Tests of Relative Importance of Autonomous Expenditures and Money.” American Economic Review 55: 729-752.

Dernberg, Thomas, and Duncan MacDougal. 1960. Macroeconomics. New York: McGraw Hill.

De Vroey, Michael (2000), "IS-LM a la Hicks versus IS-LM a la Modigliani.” History of Political Economy, 32:2.

Dornbusch, Rudiger. 1976. "Comments on Brunner and Meltzer.” In Jerome Stein (ed.), Monetarism. Amsterdam: North-Holland, 104-126.

Friedman, Milton. 1956. “The Quantity Theory of Money: A Restatement.” In M. Friedman (ed.) Studies in the Quantity Theory of Money. Chicago: University of Chicago Press, 3-21.

Friedman, Milton. 1959. “The Demand for Money: Some Theoretical and Empirical Results.” Journal of Political Economy 67: 327-351.

Friedman, Milton. 1966. "Interest Rates and the Demand for Money." Journal of Law and Economics 9: 71-85. 
Friedman, Milton. 1974. “A Theoretical Framework for Monetary Analysis.” In R. J. Gordon (ed.) Milton Friedman's Monetary Analysis. Chicago: University of Chicago Press, 1-62.

Friedman, Milton. 2001. Interviewed by John B. Taylor. Macroeconomic Dynamics 5: 101-131.

Friedman, Milton, and Walter W. Heller. 1969. Monetary vs. Fiscal Policy: A Dialogue. New York: W.W. Norton.

Friedman, Milton, and David Meiselman. 1963. "The Relative Stability of Monetary Velocity and the Investment Multiplier in the United States, 1897-1958." In Stabilization Policies, 165-268. Prepared for the Commission on Money and Credit. Englewood Cliffs, N. J.: Prentice-Hall.

Friedman, Milton, and Anna J. Schwartz. 1963a. "Money and Business Cycles.” Review of Economics and Statistics 45(2, supplement): 32-64.

Friedman, Milton, and Anna J. Schwartz. 1963b. A Monetary History of the United States, 18671960. Princeton, N. J.: Princeton University Press.

Friedman, Milton, and Anna J. Schwartz. 1982. Monetary Trends in the United States and the United Kingdom: Their Relation to Income, Prices, and Interest Rates. Chicago: Chicago University Press.

Gordon, Robert J. (ed.). 1974. Milton Friedman's Monetary Framework: A Debate with his Critics. Chicago: University of Chicago Press.

Hammond, J. Daniel. 1996. Theory and Measurement: Causality Issues in Milton Friedman's Monetary Economics. New York: Cambridge University Press.

Hansen, Alvin. 1953. A Guide to Keynes. New York: McGraw Hill.

Hester, Donald D. 1964. "Keynes and the Quantity Theory: A Comment on the FriedmanMeiselman CMC Paper.” Review of Economics and Statistics, November, 364-477 
Hicks, Sir John R. (1937), “ Mr. Keynes and the 'Classics'.” Econometrica, Vol. V, no.2, April. Reprinted in Critical Essays, Oxford Clarendon Press 1967.

Hirsch, Abraham, and Neil de Marchi. 1990. Milton Friedman: Economics in Theory and Practice. New York: Harvester Wheatsheaf.

Hoover, Kevin D. 1988. The New Classical Macroeconomics: A Sceptical Inquiry. Oxford: Blackwell.

Johnson, Harry G. 1971. "The Keynesian Revolution and the Monetarist Counter-Revolution." American Economic Review 61: 1-14.

Keynes, John Maynard. 1936. The General Theory of Employment, Interest, and Money. London: Macmillan.

Laidler, David. 1981. "Monetarism: An Interpretation and an Assessment.” Economic Journal 91: 49-55.

Lucas, Robert E., Jr. 1994. "Review of Milton Friedman and Anna J. Schwartz’s A Monetary History of the United States, 1867-1960. Journal of Monetary Economics 34(1):5-16.

Mayer, Thomas. 1978. The Structure of Monetarism. New York: W.W. Norton.

McCallum, Bennett T. 1999. “ Recent Development in the Analysis of Monetary Policy Rules.” Federal Reserve Bank of St. Louis Review, November/December (1999): 3-11.

McCallum, Bennett T., and Edward Nelson. 1999. “An Optimizing IS-LM Specification for Monetary Policy and Business Cycle Analysis." Journal of Money, Credit and Banking 31, 3 (August part1): 296-315.

Meyer, Laurence H. 2001. "Does Money Matter?” Federal Reserve Bank of St. Louis Review, September-October: 1-15. 
Miron, Jeffrey A. 1994. "Empirical Methodology in Macroeconomics: Explaining the Success of Friedman and Schwartz's A Monetary History of the United States, 1867-1960. Journal of Monetary Economics 34: 17-25.

Modigliani, Franco. 1944. "Liquidity Preference and the Theory of Interest and Money." Econometrica 12: 45-88.

Purvis, Douglas D. 1980. “Monetarisn: A Review.” Canadian Journal of Economics February: 96-122.

Stein, Jerome L. (ed.). 1976. Monetarism. Amsterdam: North-Holland.

Summers, Lawrence H. 1991. "The Scientific Illusion in Empirical Macroeconomics.” Scandinavian Journal of Economics 93 (2): 129-148.

Tobin, James. 1970. “Money and Income: Post Hoc Ergo Propter Hoc?” Quarterly Journal of Economics 84: 301-317. 